\title{
Two interesting cases of tracheobronchial foreign bodies
}

\author{
Murat Oncel, ${ }^{1}$ Guven Sadi Sunam, ${ }^{1}$ Seda Ozbek ${ }^{2}$
}

'Department of Thoracic Surgery, Selcuk University Faculty of Medicine, Konya, Turkey

${ }^{2}$ Department of Radiology, Selcuk University Medical Faculty, Konya, Turkey

\section{Correspondence to} Dr Seda Ozbek, dsadr@hotmail.com

\section{DESCRIPTION}

Case one: A 76-year-old man, who underwent a total laryngectomy 6 years ago for squamous cell carcinoma of the larynx, was admitted to emergency department as a result of aspiration of a tea spoon through the tracheostomy canula. He was in a habit of cleaning thick secretions of the upper airway, with a spoon via the tracheostomy. However, this time the spoon had slipped into the trachea. In the emergency department the chest $\mathrm{X}$-ray revealed the spoon in the right main bronchus (figure 1). The foreign body was viewed with the bronchoscope and removed with a pair of forceps. Laryngectomy or tracheostomy may cause risk for tracheal foreign body aspiration. In adults presence of a stoma should be added to the risk factors for foreign body aspiration during the habit of cleaning secretions. ${ }^{1}$

Case two: A previously healthy 8 -year child aspirated a pen cap while laughing which he held between his teeth at school. He failed to throw out the pen cap despite vigorous coughing. On presentation to the emergency department he was dyspnoeic and had severe wheezing. A chest X-ray confirmed the suspicion of aspiration of the foreign body into the right main bronchus (Figure 2).

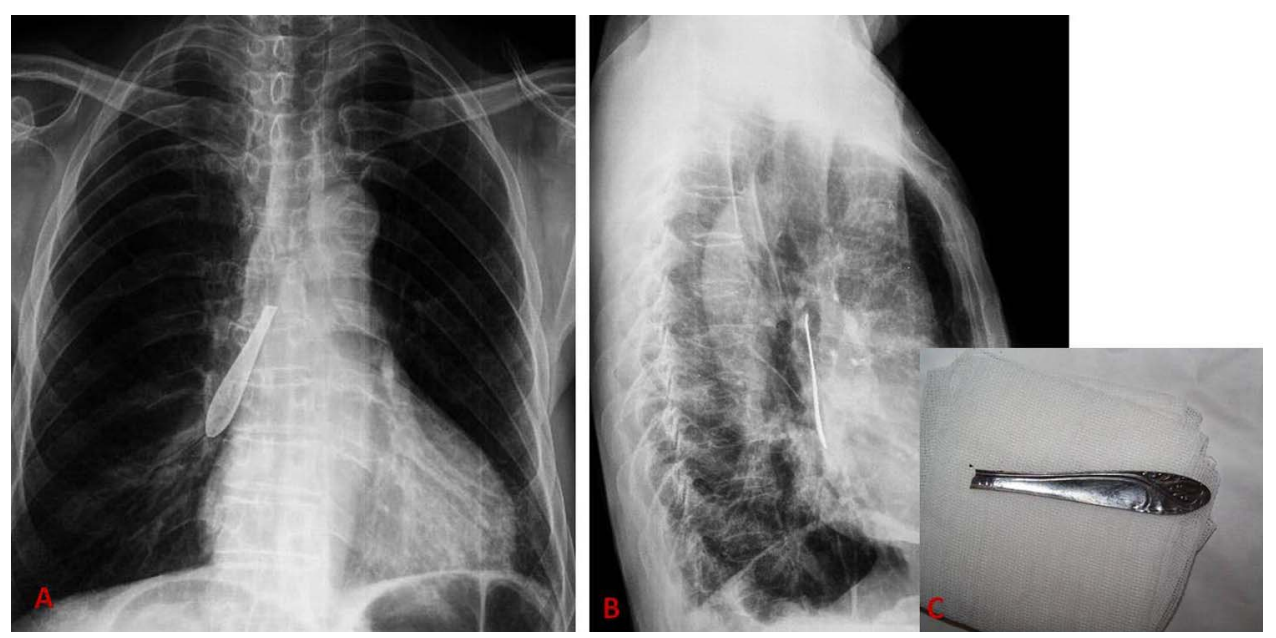

Figure 1 Posteroanterior and lateral chest $\mathrm{X}$-ray revealed the spoon in the right main bronchus $(\mathrm{A}$ and $\mathrm{B})$ and the foreign body (C).
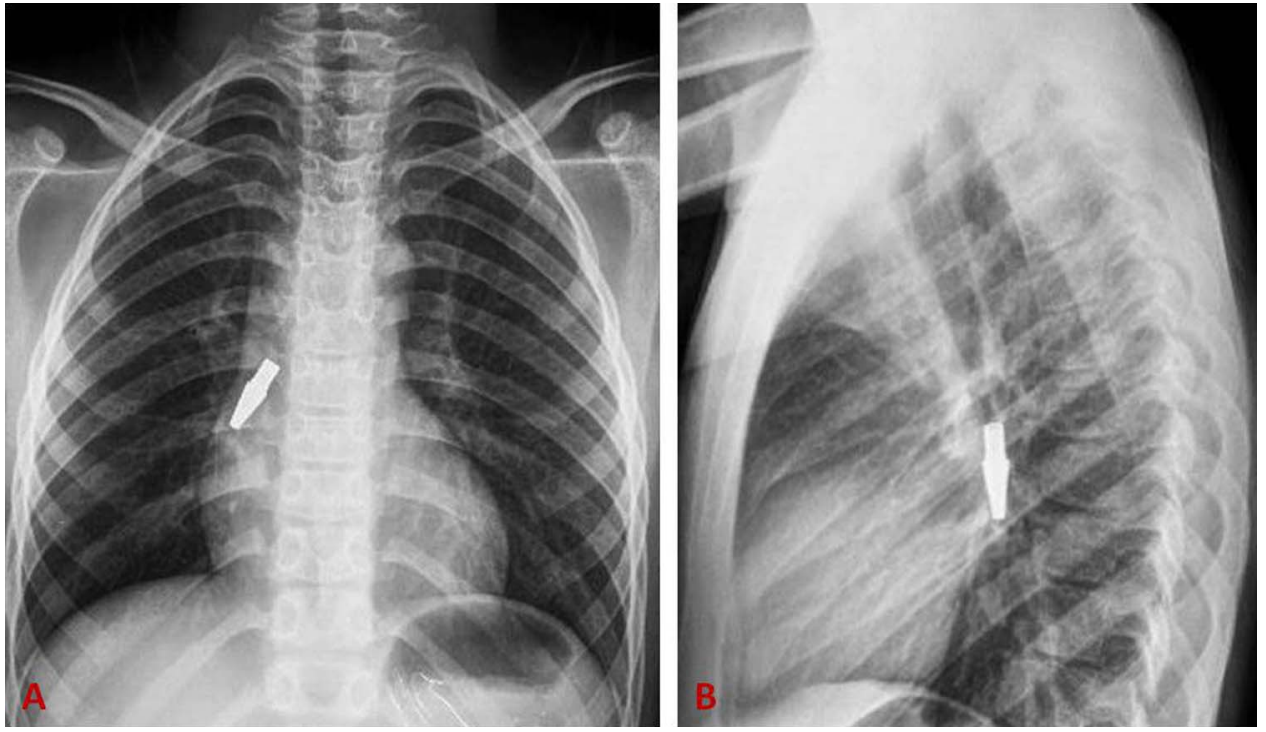

Figure 2 Posteroanterior (A) and lateral (B) chest X-ray showed the foreign body in the the right main bronchus. 
A rigid bronchoscopy was performed under general anaesthesia in the operating theater. The pen cap was viewed in the right main bronchus and successfully removed with a forceps. Tracheobronchial foreign body aspiration is a common accident in children. The diagnosis is primarily made according to a suggestive history. ${ }^{2}$ Foreign bodies on lower levels of tracheobronchial tree, may cause respiratory problems because of disrupted ventilation in distal of the obstructed level, and may lead to infection. $^{3}$

\section{Learning points}

- Tracheostomy should be added to the risk factors for foreign body aspiration during the habit of cleaning secretions.

- Rigid bronchoscopy under general anaesthesia should be performed in all children suspected of foreign body aspiration.

- Tracheobronchial foreign body aspiration is an important cause of childhood morbidity and mortality.
Contributors MO was involved in diagnosis, treatment and writing GSS was involved in diagnosis and treatment and SO was involved in diagnosis and writing.

Competing interests None.

Patient consent Obtained.

Provenance and peer review Not commissioned; externally peer reviewed.

\section{REFERENCES}

1 Krempl GA, Otto RA. Fracture at fenestration of synthetic tracheostomy tube resulting in a tracheobronchial airway foreign body. South Med J 1999;92:526-8.

2 Brkic F, Delibegovic-Dedic S, Hajdarovic D. Bronchoscopic removal of foreign bodies from children in Bosnia and Herzegovina: experience with 230 patients. Int J Pediatr Otorhinolaryngol 2001;60:193-6.

3 Swanson KL, Prakash UB, Midthun DE. Flexible bronchoscopic management of airway foreign bodies in children. Chest 2002;121:1695-700.

Copyright 2013 BMJ Publishing Group. All rights reserved. For permission to reuse any of this content visit http://group.bmj.com/group/rights-licensing/permissions.

BMJ Case Report Fellows may re-use this article for personal use and teaching without any further permission.

Become a Fellow of BMJ Case Reports today and you can:

- Submit as many cases as you like

- Enjoy fast sympathetic peer review and rapid publication of accepted articles

- Access all the published articles

- Re-use any of the published material for personal use and teaching without further permission

For information on Institutional Fellowships contact consortiasales@bmjgroup.com

Visit casereports.bmj.com for more articles like this and to become a Fellow 